\title{
متطلبات تفعيل دور منظمات المجتمع المدنى \\ في إصلاح التعليم قبل الجامعي بالعراق
}

\section{مخمد قاسم مخمد العزي}

المقدمة: - الم

و افتقار المدارس إلى المتطلبــات الأساســية التي يجب تو افر ها لتقديم مـستوى تعليمسي إلى

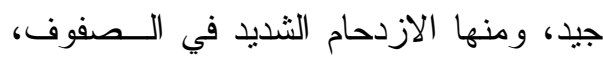

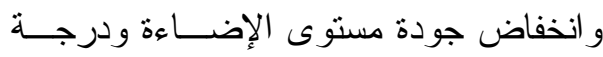
الحر ارة ووضيعة الأثاث المستخدم في غرفة الإنة ودن الصف، والتي تكون في كثير مــن الأحبــان غير مريحة أو مقاعد مكسورة، ناهيك عمــا فئا

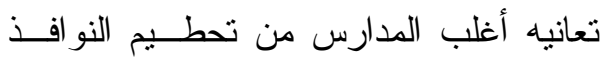
والأبو اب بسبب اضطر اب الأوضاع الأمنية وقلة توفير المستلزمات الدراســية، ومنهـــا

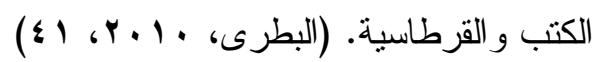
وقد أفرزت المرحلة الـسياسية فـي العر اق مفاهيم جديدة لم تكن مألوفة عمليًا في لإني الإطار الفكري و السياسي العر اقي، من قبيل (الديمقر اطية، الانتخابات، التعددية، الفدر الية،

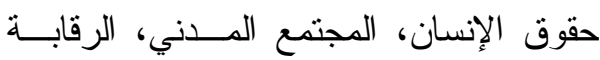

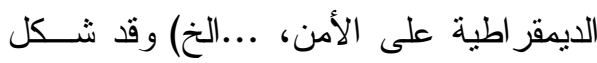

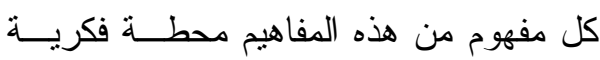

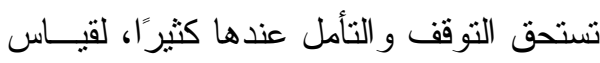
دور ها ووظيفتها في بناء أو إعادة بناء الدولة على أسس وطنية ديمقر اطية مناسبة، في ظل فل فوضى عارمة وخطيرة في تحديد المفــاهيم
يُعد التعليم مطلباً أساسياً من منطلبات

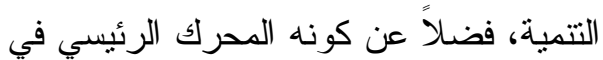
تطور الأمة وبناء الحضار ات الذي لا يتم إلا

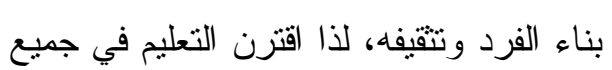

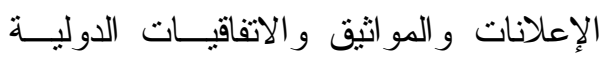
بحقوق الإنسان. و على الرغم من أن العراق في فتـــرة

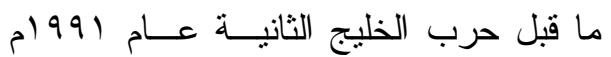

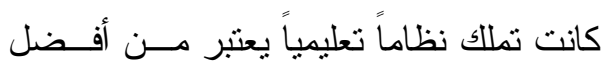

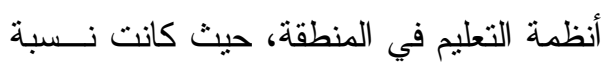
القادرين على القراءة و الكتابة عالية، وكادت

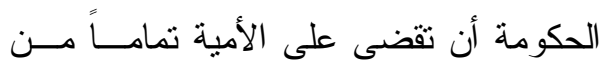

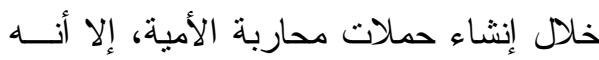

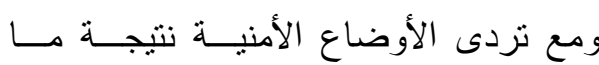

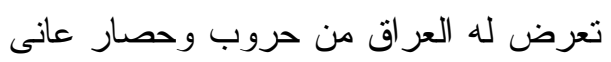
التعليم الكثير من المشكلات، حيث صنس هـارت الأفكار الهدامة و التقرقة المذهبيــة (حمــزة،

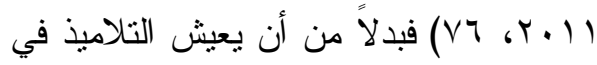

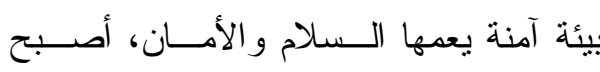
التلاميذ يعيشون مخاوف كثثرة حتــى أثتــاء وجودهم في المدارس أو ذهابهم إليها، هــــا إلى جانب ضعف كفاءة الإدارات المدرسـية 
مسـسلوب الإر ادة لــشخص أو جماعـــة أو

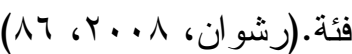

إن المجتمع المدني يشكل رأس مسـال المجتمع ومناخ جد ملائم للتتمية، وأن قــوة لـن المجتمع الاقتصادية مرتبطة بقوة المجتمـع

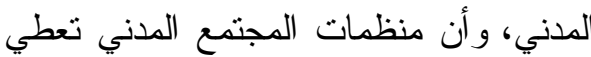
أعضاءها مجموعة كبيــرة مــن المهــار ات وشبكة واسعة من الاتصالات تتيح لهم فرص فر

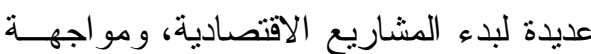

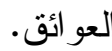

خاصة في ظل ما تو اجهه المنظومـــة

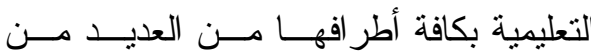
التحديات أخطر ها ما يعرف بظاهرة العولمة،

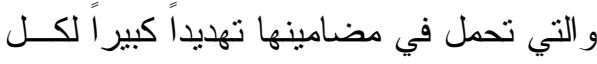
المجتمعات، وهذا التهديد شمل كل من الدول

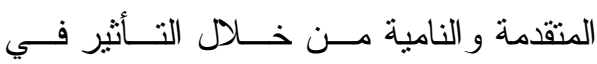
مقومات المواطنة و الو لاء عند أفر ادها. فقضية إصلاح التعليم كانت و لازالت إحدى المحاور الهامة التي تضمنتها وثثيــة

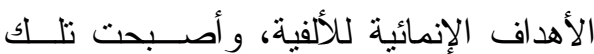

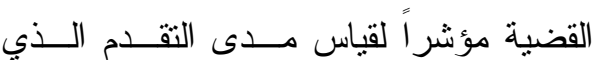
تحرزه العراق في طريق الأصل.

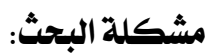

في ضوء ما ســـق عرضــه، وفـي

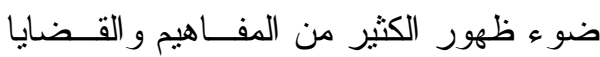
المعاصرة منل حقوق الإنــسان و المو اطنــة فئة
و الثركاء الفاعلين في الساحة السياسية لتتفيذ بر امج التغيير و البناء، مع وجود تدخل أجنبي

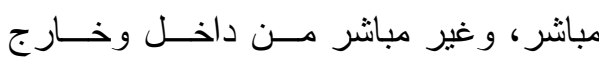

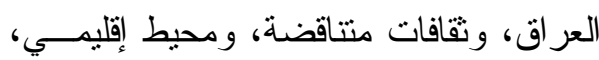

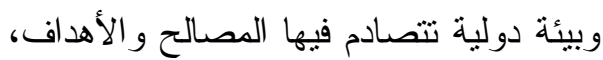
ومن بين كل هذه التعقيدات نلاحــ حالـــة

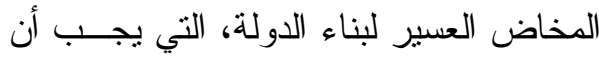
تكون قوية من أجل المو اطن، وليس ضــــه،

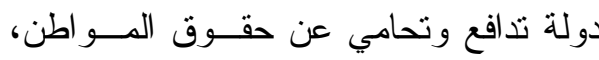
وليس دولة تتفنن في انتهاك هــــه الحقــوق، يُسخر فيها القانون لخدمة أفــر اد الــسلطة.

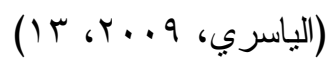

فالمجتمع المدني في العراق ضرورة

قصوى فهو يساعد على امتصاص التوترات الناجمة عن الاختلافــات العرقيــة و الدينيـــة

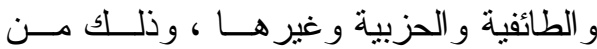
خلال تركيزه على مبدأ المو اطنــة ، حيـــث

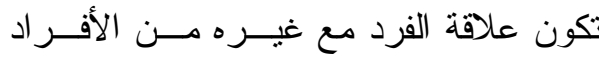

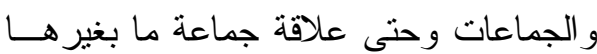

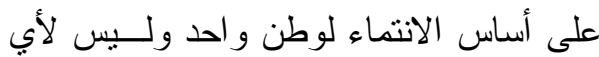

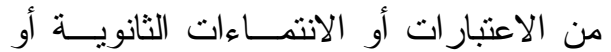

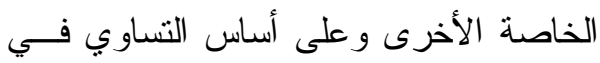

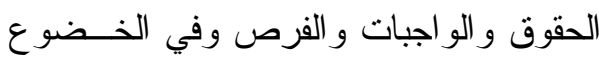
للقانون و الامتثال لأحكامه وحيث يكون الفرد

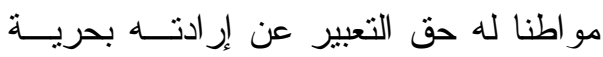

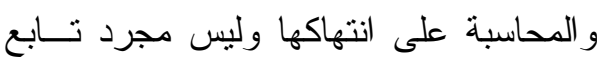




\begin{tabular}{|c|c|}
\hline 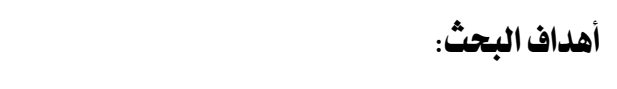 & و المشتاركة و العدالـــة الـــسياسية و أهميتهــــا \\
\hline تهدف الدراسة الحالية إلــى محاولــة & و المسئولية الاجتماعية وصور ها و القـانون \\
\hline الوصول لتفعيـلـ دور منظمــات المجتمــع & و الدستور و الحقوق و الو اجبــات و غبر هـــا، \\
\hline المدني بالعر اق في إصـــلاح التعلـــيم قبــلـ & و التي تتخذ من التعليم الركيـزة الأساســـية \\
\hline الجامعي من خلال الإجابة عـن تـساؤلات & و الأداة الرئيسية في نتمية المجتمعات، و التي \\
\hline 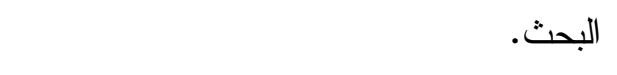 & تقرض منظمات المجتمع المــنـي ضــرورة \\
\hline 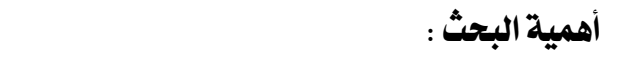 & المشاركة في قضايا المجتمع نـشأت فكـرة \\
\hline تتبع أهمية الاراسة الحالية من الآتي: & الدر اسة الحالية، و الذي أمكن صياغة مشكلته \\
\hline () أهمية القضية التي يتتاولهــا ، وهـــي & في التساؤل الرئيسي التالي: \\
\hline قضية التعليم و التـــي تبــرز كقــية & كيف يمكــن تقعيـلـ دور منظمـــات \\
\hline مستقلة أو كجزء رئيسي من قـضايا & المجتمع المدني بالعر اق في إصـلاح التعلــيم \\
\hline التتمية الاجتماعية و الاقتصادية . & قبل الجامعي في ضوء بعــض المتغيــرات \\
\hline r) انساع قطاع المستقيدين من نتائج هذا & المجتمعية؟ \\
\hline البحث وفي مقدمته المهتمين بقضايا & ويتفرع من هذا التسـاؤل الرئيسي الأســئلة \\
\hline 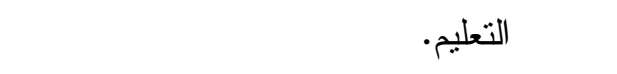 & الفرعية الآتية: \\
\hline r) أهمية وظائف مؤسـسـات المجتمـع & () ما الإطار الفكري الحــاكم لإصـــلاح \\
\hline المدني، و التي تتمنل في تحقيق النظام & التعليم قبل الجامعي في العراق؟ \\
\hline في المجتمع الحـــافظ عـــى حقـــوق & ץ) ما فلسفة منظمات المجتمــع المــدني \\
\hline الأفر اد و الفئات و الجماعات و الــدفاع & 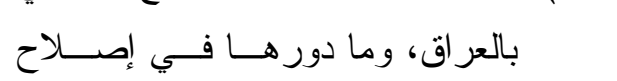 \\
\hline عن حقوق الإنسان، وتخفيف العــبء & التعليم قبل الجامعي؟ \\
\hline عن كاهل الدولـــة ، و إقامـــة قو افــلـل & r) ما أهم المعوقات التي تحول دون قيام \\
\hline صحية، و المشاركة الفعالة في العملية & منظمات المجتمع المدني بدور ها في \\
\hline التعليمية. & إصلاح التعليم بالعر اق؟ \\
\hline 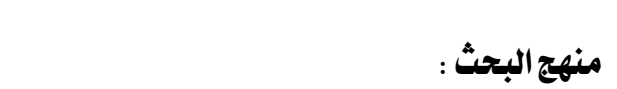 & ع) ما منطلبــات تفعيـلـل دور منظــــات \\
\hline الوصفي، و الذي ستتضح ختخدم الدراسة الحالية المنهج & 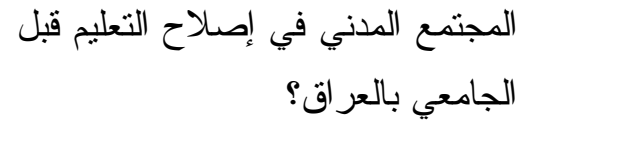 \\
\hline
\end{tabular}


يعرض البحث الحالى الدر اسات السابقة كما يلى: اليعرص:

أولاً: الدراسات العربية: ا - دراسة بلر وآخرون (^ . ㄷ) بعنوان: المجتمع المدني وسياسات الحوار حول

التعليم للجميع في المنطقة العربية.

هدفت الدراسة التعـرف إلـى دور

و آليات الثر اكة بين منظمات المجتمع المدني

و الحكومات الوطنية، واســتخدمت الدر اســة لئة

المنهج الدقـــارن فــي تحليـل الاســنبانات

و المقابلات و اللقاءات التي تمت مع مسئولين

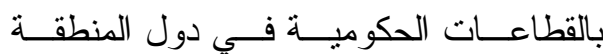

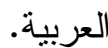

واستخدمت الدراسة استبانه للشبكات

و الائتلافات ومنظمات المجتمع المدني و أسئلة

موجهة إلى القيادات الحكومية بقطاع التربية

$$
\text { و التعليم. }
$$

وشملت عينــة الدراســـة علــى (0)

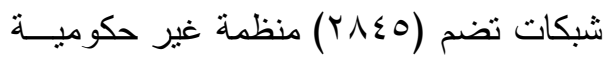
في (19) دولة عربية.

ومن أهم النتائج التى توصلت إليهــا

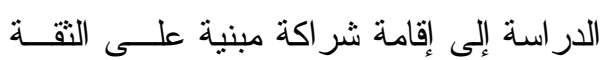

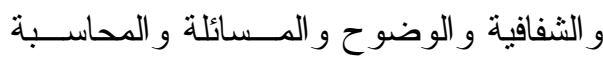

وتطوير الأداء بين الثركاء و إقامة حوارات

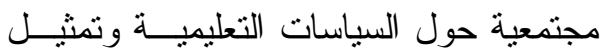

منظمات المجتمع المدني و الثبكات الوطنيـــة

لقضية إصلاح التعليم في العراق، ومنظمات المجتمع المدني المهتمة بهذه القضية محليـاً و عالمباً، وكذلك في الوقوف على و اقع الدور

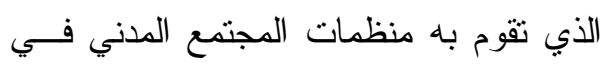
إصلاح التعليم قبل الجامعي بالعر اق، و أخيراً

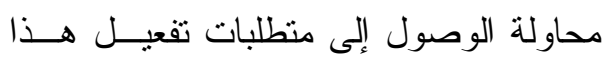

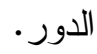

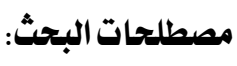
• إصلاح التعليم : تعــرف الدراســـة الحاليـــة إصـــلاح

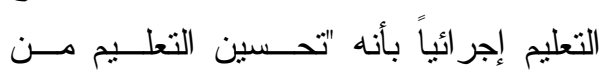
خلال إصلاحات جزئية أو كلية فـــي نظــام

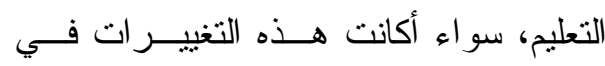

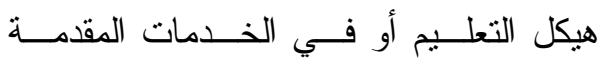
للتعليم أو الإجر اءات. • منظمات المجتمع المدني: تعرف الدراســة الحاليــة منظمــات

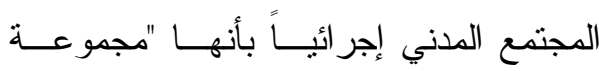
المؤســسات التطو عيــة الحــرة الــسياسية و الاقتصادية والاجتماعية و الثقافية التي تعمل لفوله

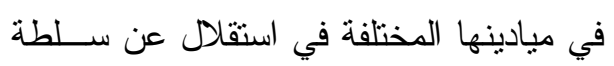
الدولة لتحقيق أغر اض متعددة، وهي بـــللك تعد جزء من حياة المجتمع الخارجة عن حيز

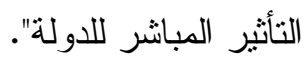
الدراسات السابقة: - الديز 
تأثثر على عملية التغيير الايجـابي ويعتبــر

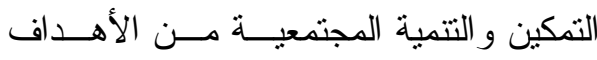

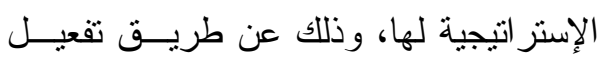

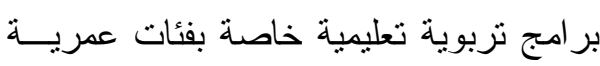

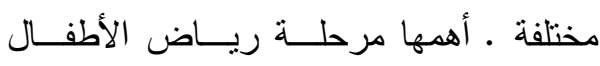

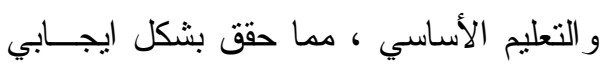

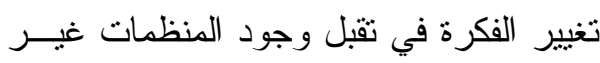
الحكومية في المنطقة العربيــة ، و الإيـــان

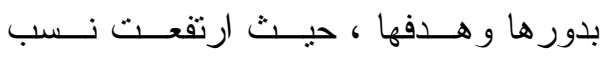
الالتحاق بالمدارس ، و انخفضت نسب الأمية

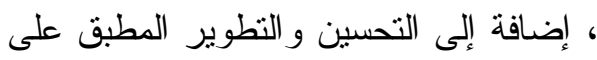
المدارس من أنظمة ، ومناهج و أبنية ، كذلك التطـــوير الحاصــل فــي أســاليب التعلــيم و التدريس و التدريب ، إلا إنها تعـاني مسنـ

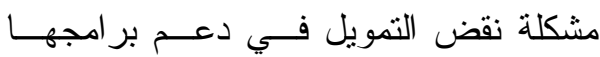

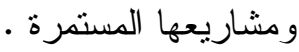

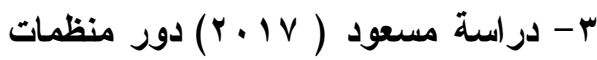
المجتمع المدني في تطــوير المنـــاهج وتحسين طرق التدريس فــي الــضفة

$$
\text { الغربية }
$$

هدفت الدر اسة إلــى دور منظمــات المجتمع المدني في إصلاح المناهج وتحسين لـاني طرق التدريس بمختلف عناصر المناهج من

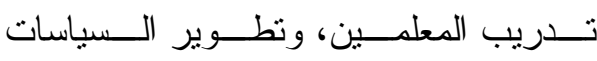
التربوية، و إعداد الوسائل التعليمية، وتطوير

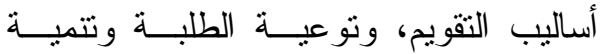
و عيهم، وتأهيل المؤسسات التعليمية وبنيتهــا

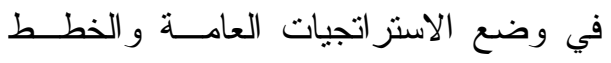

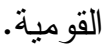

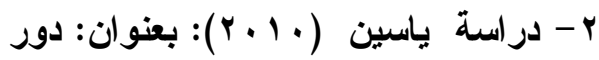

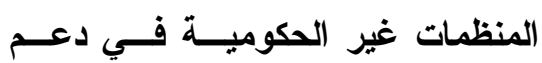
التعليم في الأردن.

هدفت الدر اسة التعرف إلــى الــدور الذي تقوم به المنظمات غير الحكومية فـي إني

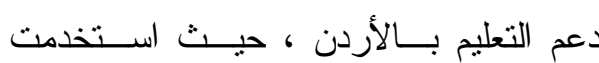

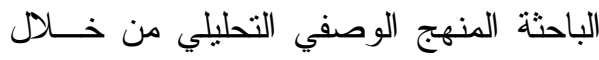
الزيارة الميدانية و إجر اء المقابلات الثخصية مع إدارة المنظمات . ميل وتكون مجتمع الدراسة مسن جميـع المنظمات غير الحكومية المحليــة و الدوليـــة العاملة في مجال التعليم ثم أخذ عينة قصدية من أربع منظمات غيــر حكوميـــة محليـــة

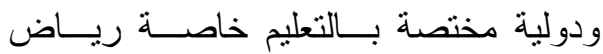
الأطفال ومرحلة التعليم الأساسي ، وقد بينت

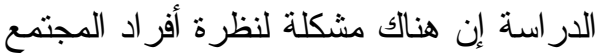
وثقافته حول مفهوم المنظمات غير الحكومية ، بالتالي يجب الــسعي إلــى تغييـــر نقافــة المجتمع، ونظرته نحو وجود هذه المنظمات بات لهات

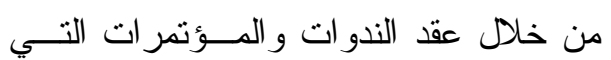
تتظمها المنظمات غير الحكومية بالتعاون مع وع مؤسسات القطاع الحكومي . ومن أهم النتائج التى توصلت إليهــا

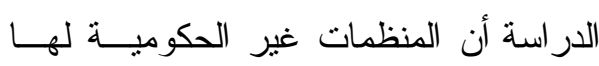


الأساسي في ز امبيا، كما هدفت أيـضـاً إلـى

تحديد التحديات التي نو اجهها هذه المنظمات

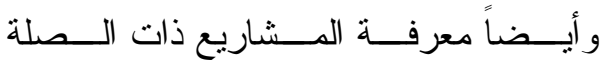
بالمنظمات غير الحكومية، و التــي نوفرهــــا لمرحلة التعليم الأساسي و الثانوي في ز امبيا. وقد تم استخدام عينة عشو ائية بسيطة حيث شاركت (· (1) منظمات غير حكوميــة و(·. (1) فرد في الإجابة على الاسـنتيانات الخاصة بهذه الدر اسة.

ومن أهم النتائج التى توصلت إليهــا الدراسة دور المنظمات غير الحكومية فــي لوني توفير الغذاء ودفع الرسوم المدرسية لأطفال

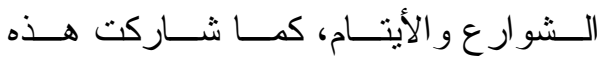

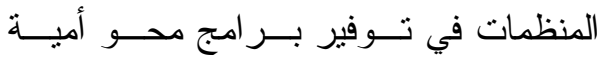

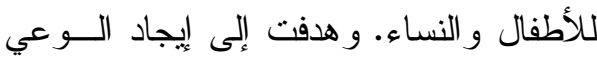
وتتقيف المجتمعات المحلية وتعليمهم القراءة و الكتابة، إضافة إلى توفير حياة أسرية أفضل وتحسين نوعية حياة الإنسان. r- دراسة بارك (Park, 2015) بعنوان: (تصورات المنظمات غيــر الحكوميــة الكورية للتعلـيم ومسشـاريع تطــوير

$$
\text { (التعليم) }
$$

هدفت الدراسة إلى تحديــــ ملامــح

مشاريع التعاون الإنمائي التعليمية للمنظمات

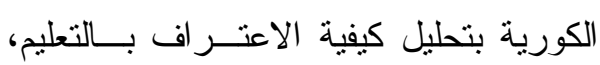
ومشاريع التعليم على اعتماد جدول أعمــال
التحتية، وتفعيل الثر اكة المجتمعية .

استخدم الباحـث الإســنبانه لجمــع

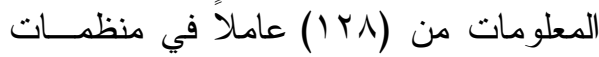
المجتمع المدني، و المقابلات الثخصية مــع

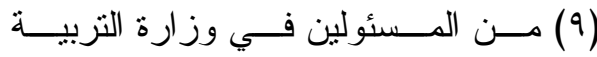
و التعليم

ومن أهم النتائج التى توصلت إليهـــا

الدر اسة إلى أهمية دور المنظمات في تدريب المعلمين، ودور المنظمات في تتمية الطلبـــة وتوعيتهم، ودور المنظمات في تأهيل بيئــة المؤسسات التعليمية، ودور المنظهــات فــي ودي

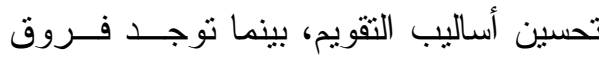
ذات دالة إحصائية في مجالات العالقة بـين

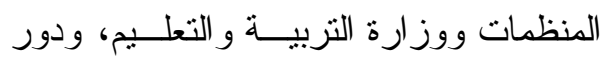

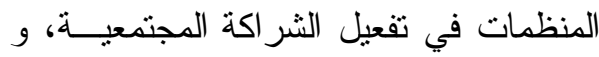
دور مؤسسات المجتمع المدني فـي صــنـع

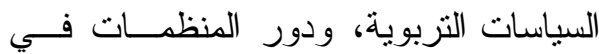
تطوير المحتوى التعليمي، ودور المنظمــات في تطوير الوسائل التعليمية، والدرجة الكلية

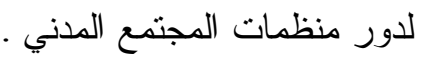
ثانياً: الدراسات الأجنبية: ا - در اســــة ســـيدني (Peggy, 2012) بعنوان: دور المنظمات غير الحكوميــة في دعم التعليم في ز زمبيا هدفت الدر اسة التعرف إلــى تــأثنير المنظمات غير الحكومية في توفير التعلــيم 


$$
\begin{aligned}
& \text { التعليمية وضرورة الاهتمام بها، وقد كــان } \\
& \text { مضمون بعض هذه الدر اســات قريــــاً مــن } \\
& \text { مضمون الدر اسة الحالية وكان البعض الآخر }
\end{aligned}
$$

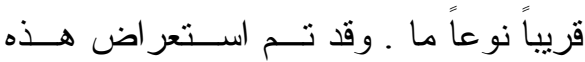

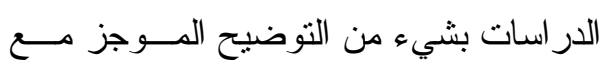

$$
\begin{aligned}
& \text { النزكيز على أهم النتائج الني نوصلنا اليها. } \\
& \text { المحور الأول: إصلاح التعليم قبل الجامعي: } \\
& \text { أصــبح مــن المــسلمات اليــوم أن }
\end{aligned}
$$

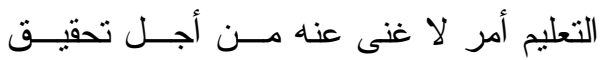

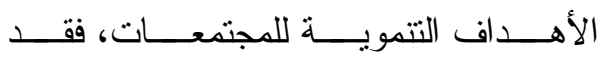

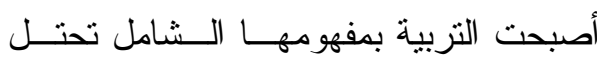

$$
\begin{aligned}
& \text { مكان الصدارة في كافة المجتمعــات حيــث }
\end{aligned}
$$

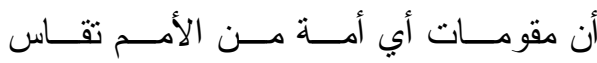

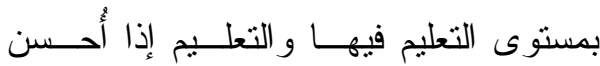

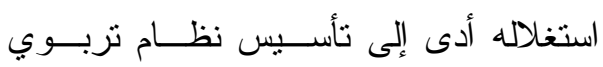

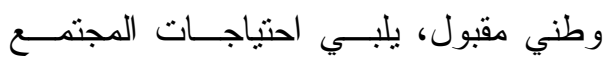

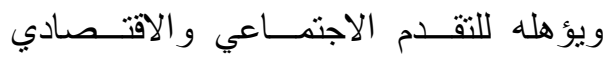

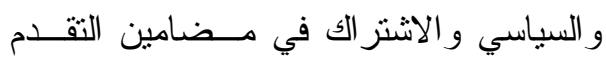

$$
\begin{aligned}
& \text { الحضاري و التكنولوجي. } \\
& \text { أولاًِ- مفهــــوم إصــــلاح التعلـــيم قبــــل } \\
& \text { الجامعي }
\end{aligned}
$$

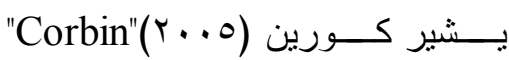

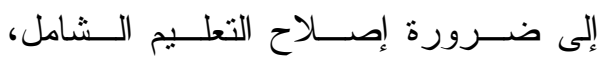

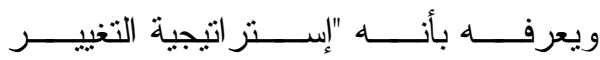

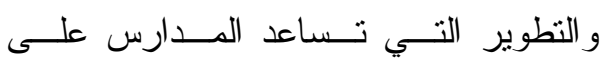

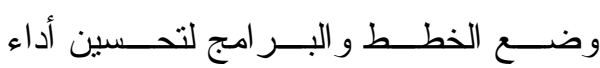

$$
\begin{aligned}
& \text { إلانمائية الوطنية في مشاريعها. } \\
& \text { اعتمد الباحث على المةــابلات الثخـــية } \\
& \text { وتحليل الوثائق. } \\
& \text { ومن أهم النتائج التى توصلت إليهــا }
\end{aligned}
$$

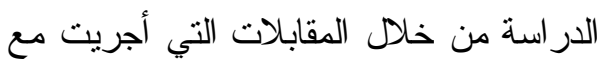

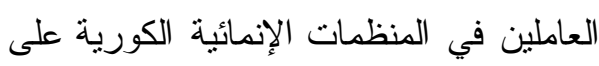

$$
\begin{aligned}
& \text { الرغم من أن مفهوم التعليم ومشاريع التعليم }
\end{aligned}
$$

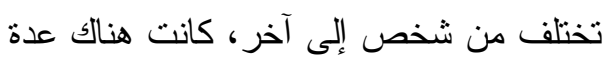

$$
\begin{aligned}
& \text { نقاط مشتركة مثيرة لاهتمام تتاسب المشاريع }
\end{aligned}
$$

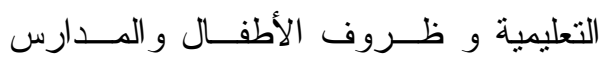

$$
\begin{aligned}
& \text { وتحقق مشاريع تعليم التتمية المجتمعية فتميل } \\
& \text { إلى تتفيذ المشاريع التي يمكن أن تخلق نتائج }
\end{aligned}
$$

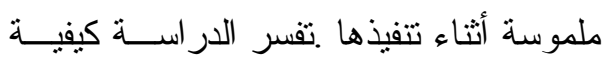

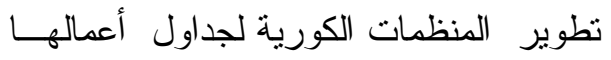

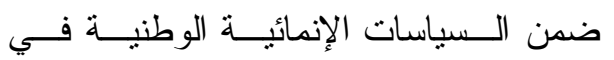

$$
\begin{aligned}
& \text { مشاريع التعليم، فالمنظمات تميل إلى اختيار } \\
& \text { مشاريع التعليم و تسعى لتحقيق نتائج ملموسة } \\
& \text { على المدى القصير ، وهذا مستمد من التركيز }
\end{aligned}
$$

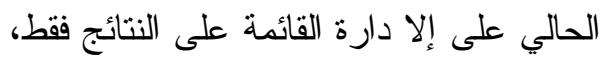

$$
\begin{aligned}
& \text { مما دفع المنظمات الكورية لتصميم مشاريع } \\
& \text { تعليمية تحقق المستدامة. }
\end{aligned}
$$

\section{تعقيب على الدراسات السابقة}




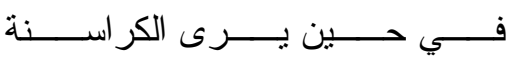

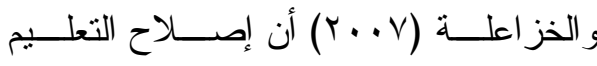
قبل الجامعي ينبغي أن يقوم علــى "الــسعي الدعوب لتغيير و اقع المدرسة الحــالي مــن خلال تغيير مــدارك الأفـر اد وممارســاتهم فيها وجعلهــا متمحسـورة حــول العنـــر

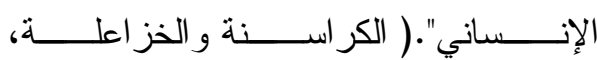
$(1 \cdot 6 r \cdot V$

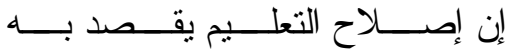

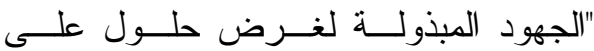

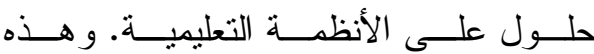
الحلول تتــمن بــر امج قــر اءة جديــــة بـــر امج تربويــــة، و إدارة جيـــدة، و أحيانــــاً

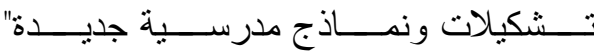

(Sophia, 2006, 10)

ومما تقدم من تعريفات لمفهــوم إصــلاح التعليم يمكن التوصل للآتي:

إن هناك شبه اتفــاق بــين البــاحثين

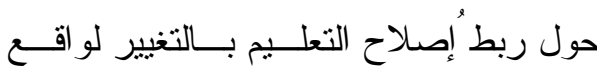
المدرسة نحو الأفــض، مـــع التـــوع فــي

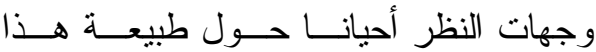
التغيير • ففي حــين ربـــ هـس إصـــلاح

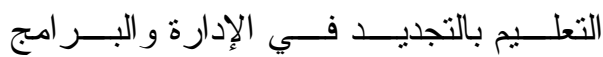

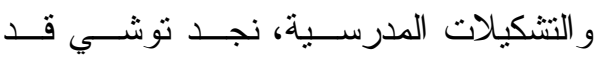
دعا إلى استخدام نمـــوذج موحــد وشـــامل لجميع عناصــر النظــام المدرســي، فـي حين ربط الصغير إصلاح التعلــيم وتقـــيم

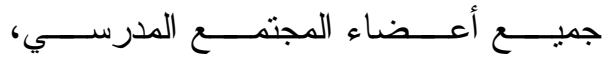

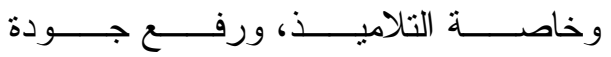
Corbin,2005, (المخرجــات المدرســية"

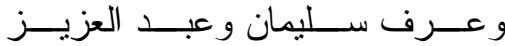

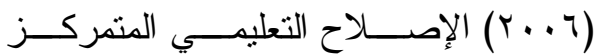
على المدرسة بأنه: "الإصـلاح القـائم علـىى

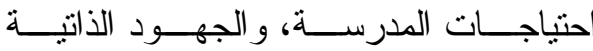
للعاملين فــي المدرســـة و المـــؤثرين فــي

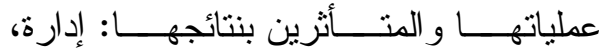
معلمين، تلاميذ، أعضاء مجلــس الأمنـــاء، أولياء الأمور، أفــر اد المجتمــع المحلـي، و غيرهم من المعنيين الأخــرين".(ســليمان

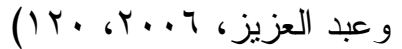

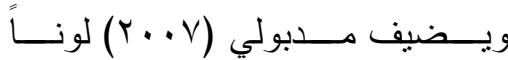
جديداًإلى مفهـــوم إصـــلاح التعلــيم حيـــث يرى "ضـــرورة أن يرتكــز إلــى المهنيــة الواعية بخصوصية كـلـ مدرســة، حيـــث يبادر المعلمون و الإداريــون و القــادة إلــى

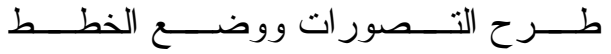
وتتفيذها فــي إطــار إمــتلاكهم لتجــربتهم الخاصة، مــوجهين بنتــائج مـــا يقومــون بإجر ائه من بحوث فــي مدارســهم، لــيس

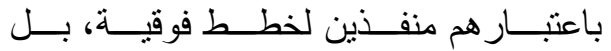
بوصــــهم لاعبــين أساســين"( مـــدبولي، $\left(r r^{\prime}, r \cdot v\right.$ 


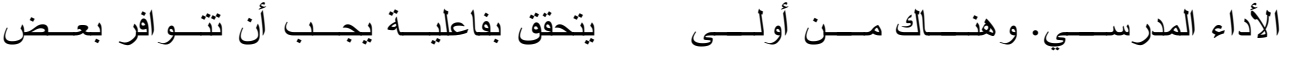

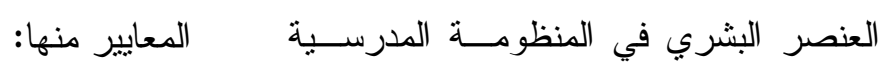

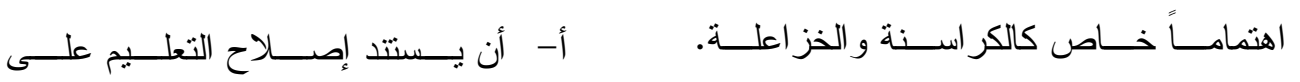

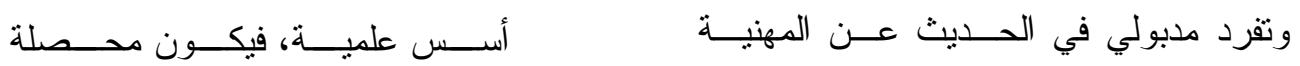

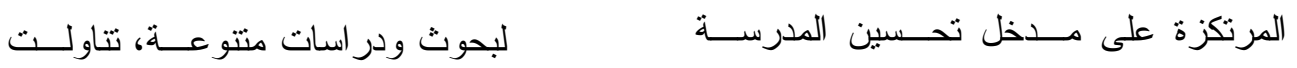

$$
\begin{aligned}
& \text { معتمداً على ما حققـهـه هـــا المفهـوم مــن }
\end{aligned}
$$

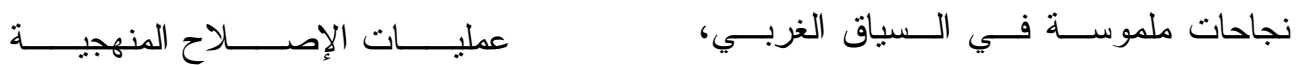

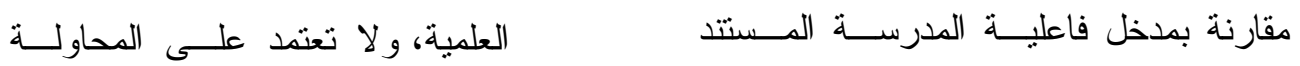

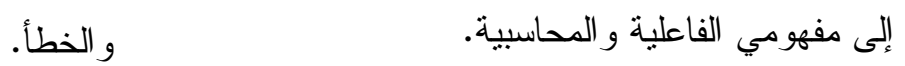

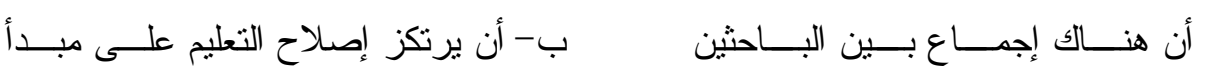

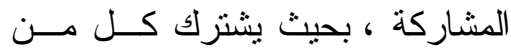

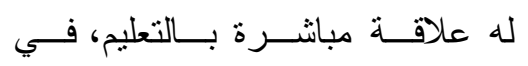

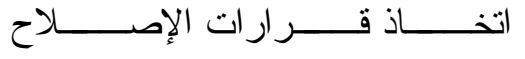

$$
\begin{aligned}
& \text { و المشاركة في تنبيها وتتفيذها. } \\
& \text { ج- توفر القيــادة القـادرة علــى حـشند }
\end{aligned}
$$

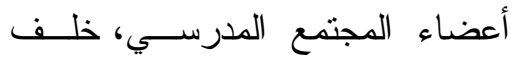

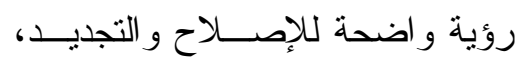

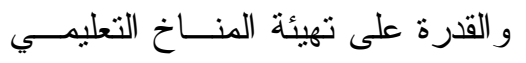

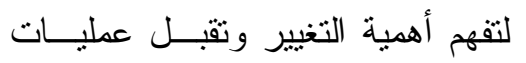

$$
\begin{aligned}
& \text { الإصلاح ودعمها. } \\
& \text { د- تـــوفر المعلومـــات، حيـــث يحتـــاج } \\
& \text { تطبيق إصلاح التعلــيم إلــى تــوفر }
\end{aligned}
$$

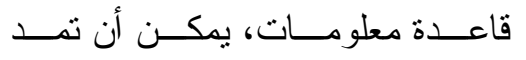

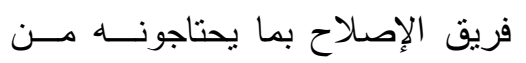

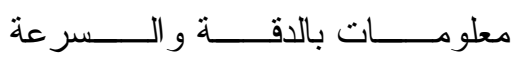

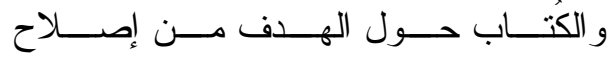

$$
\begin{aligned}
& \text { التعليم، وهو التحــسين الــشـامل للمدرســة، } \\
& \text { وتحــــــين تحــــــيل الطلبـــــة، و الإداء }
\end{aligned}
$$

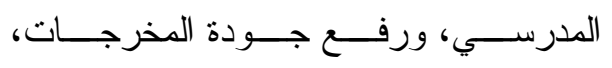

$$
\begin{aligned}
& \text { و الارتقاء بالمجتمع. } \\
& \text { ويمكن بلــورة التعريــف الإجرائسي }
\end{aligned}
$$

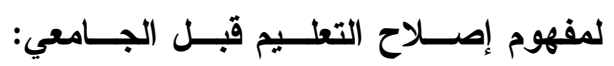

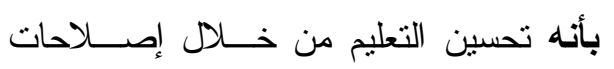

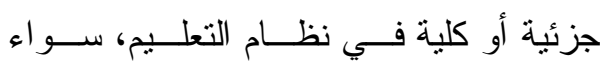

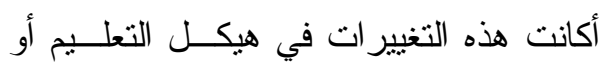

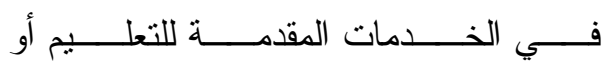

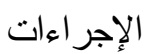

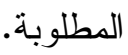

$$
\begin{aligned}
& \text { أضحى إصـــلاح التعلــيم ضـــرورة } \\
& \text { حياة القــرن الحــادي و العـشرين، ولكـي }
\end{aligned}
$$


ثالثاً - مقومات إصلاح التعليم:

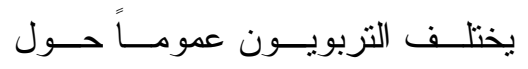

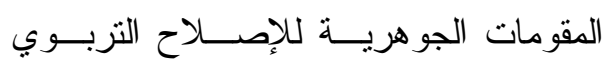

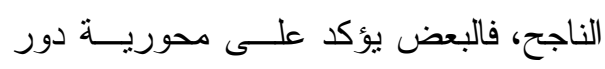

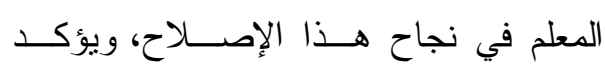

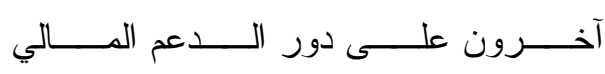

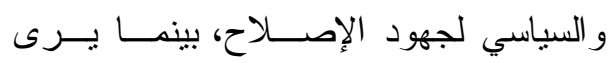

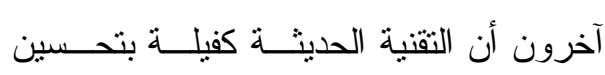

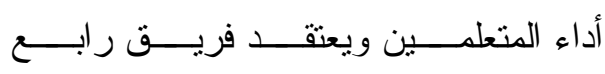

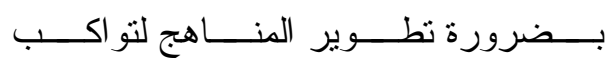

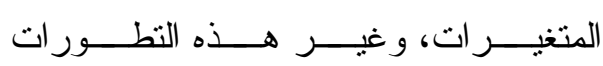

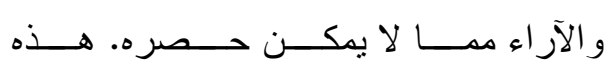

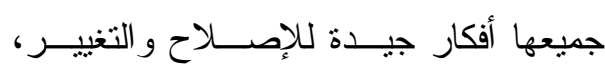

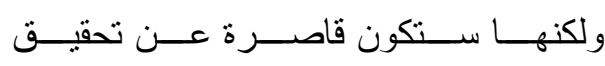
إصلاح التعليم المنشود إذا لم تتطلــق مــن

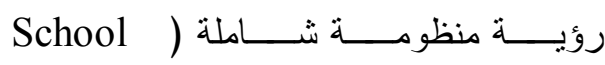
(Reform Comprehensive

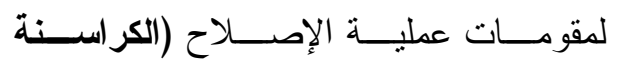

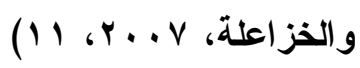

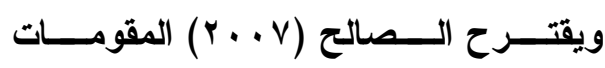
الرئيسية التالية لإصلاح التعليم:

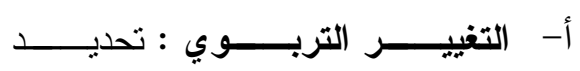

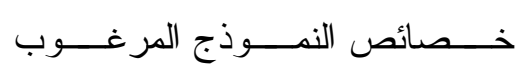

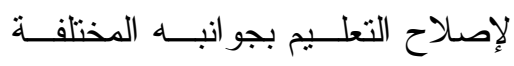

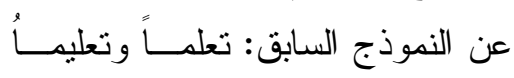

و إدارة. - من
هـ - تــوفر المـــوارد البــشرية و الماديــة

و المالية اللازمة لعمليــات إصـــلاح التعليم.

وأنه وبغــض النظـــر عـنـ البــديل

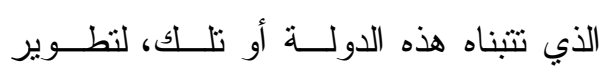

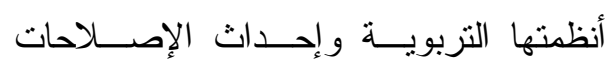

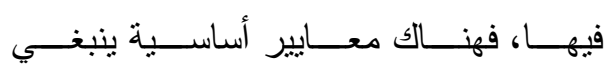

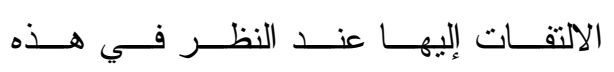

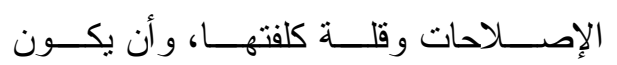

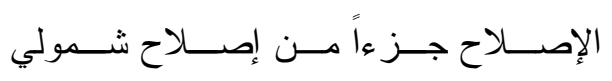

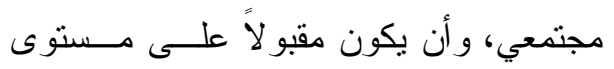

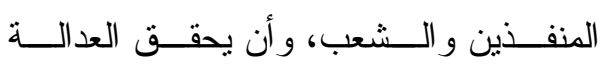

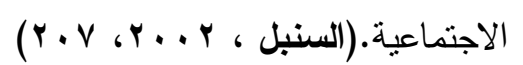

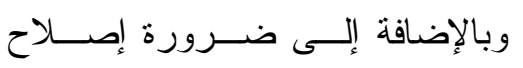

مكونات السياق المجتمعـــي المختلفــة التــي ترد منها مدخلات نظــام التعلــيم، و إليهـــا تصدر نواتجه، فأن عمليــة إصــلاح نظــام

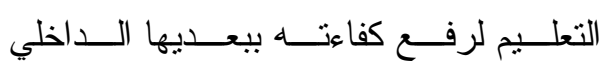

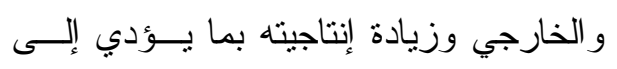

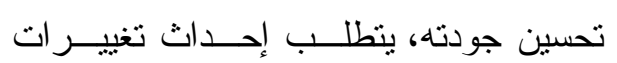

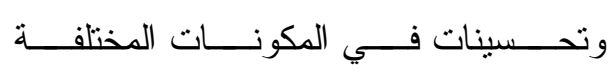

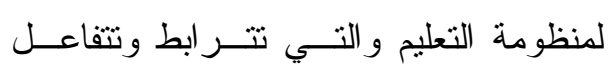

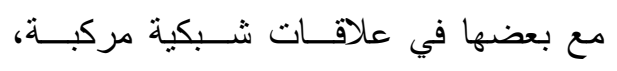

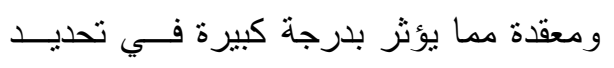
شكل ومـستوى النــو اتج النهائيـــة لنظــام التعليم.(الحوت، 1 ... Y، 9 9 1) 
نجاح جهــود إصــلاح التعــــم. بالإضــافة

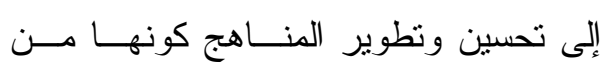
المقومات الهامة من أجل تحقيــق إصـــلاح

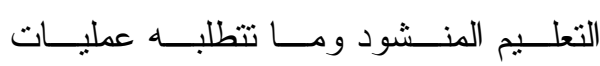

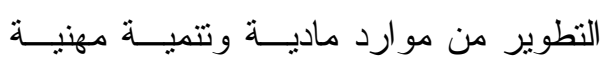

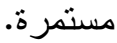
المحور الثاني: مساهمة المجتمع المدني في إصلاح التعليم: في السنوات الأخيرة زاد الحديث عن

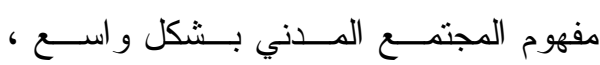

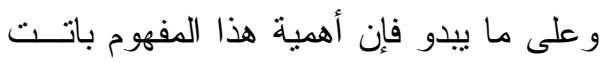

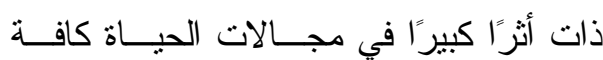
بسبب الدور الفعلي للمجتمع المــني فـي استيعاب الفراغ أو الخلل الناتج عن تـشعب

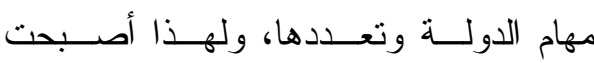
مؤسسات المجتمع المدني في علاقة تواصل

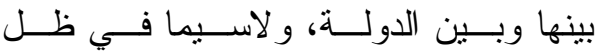
المتغيرات و التحو لات التي أفرزت مشكلات ولهات لهات عدة أسهمت إلى حد كبير في لجوء الكتيــر من الأفراد إلى هذه المنظمات أو المؤسسات لإيجاد مخرج أو حلول لهـــه المـشكلات. و لازمات الو اقع العر اقي الذي يعــاني مــن

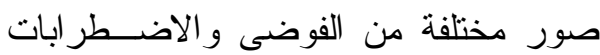

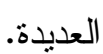

ب- تطــوير التعلــيم: تطبيــق العمليــة

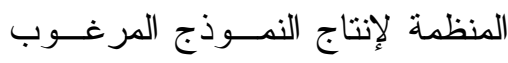
لإصلاح التعليم. لإنتاج.

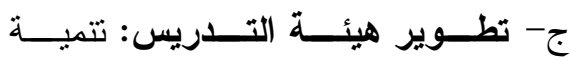

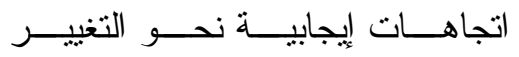

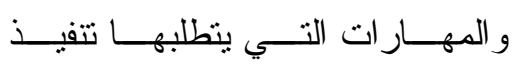
· التغيير

د- تطوير المنظمة:

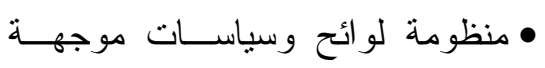
•للتغيير

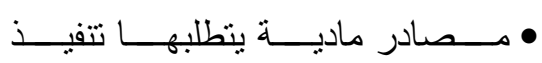
- التغيير

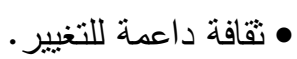

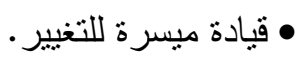

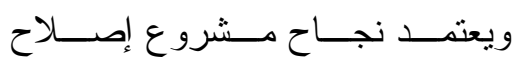

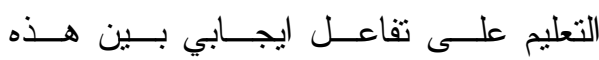

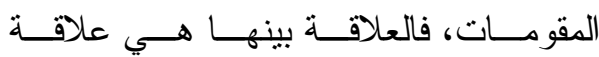

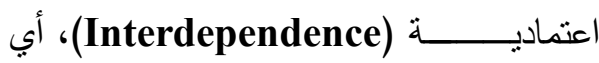
أن من غير المحتمـلـل أن يــنجح إصـــلاح

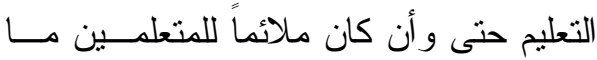
لم يصاحبه تهيئة مناسـبة لهيئــة التــدريس وللبيئة الحاضنة بكل اســتحقاقاتها الماديــة و الثقافية

$$
\begin{aligned}
& \text { فالبحـــث يــــري أن المعلـــم مـــن } \\
& \text { المقومات الأساسية والــرورية لإصــلاح }
\end{aligned}
$$

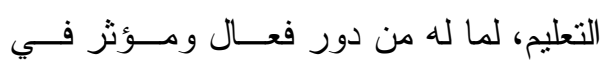


في المجتمع، وتحديد كيفية الحفــاظ على مصالحهم في مو اجهة مصالح الفئات الأخرى، وصياغة محددة قد تكون جزئية في بعض الأحيــان أو ولئ

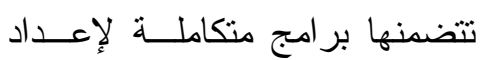

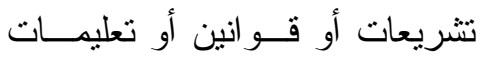

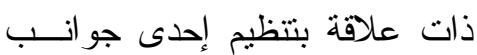

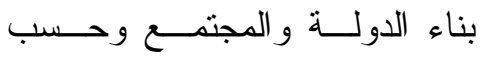

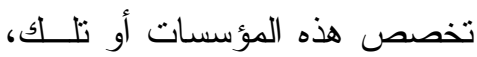
وبهذا فإن وظيفة تجميع المـصالح

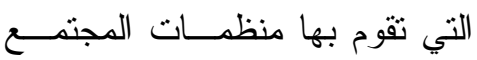

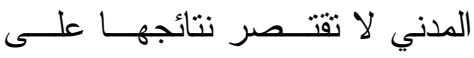

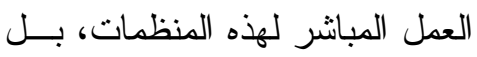
تمثن إلى المجتمع فتوفر لأعــضائه

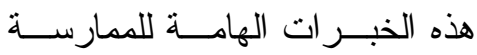

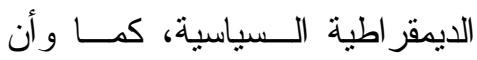

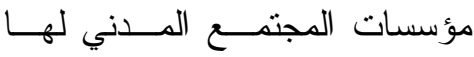

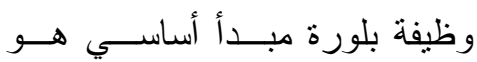
التضامن الجمعي لأعضائها، باتخاذ موقف جماعي موحد لحل مشاكلهم الداخلية ولتحقيق مصالحهم المهنية، و النقابية، بعيدًا عـنـ أي تــدخل لا يخدم مصالح أعضاءهم، كنقابـات العمل و المنظمات المهنيــة التــي

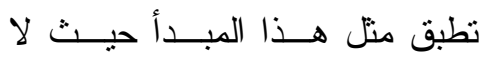
يقتصر على تلك المنظمة لوحدها،

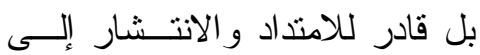

أولاًَ- مهام مؤسسات المجتمع المدني.

إن لمؤسسات المجتمع المدني مهام إزاء الايمقر اطية كنظام أو إزاء المجتمــع ككل، ومن أهم هذه المهام هي:

1- دور ثقافي وتعبوي يتحقق من خــلال

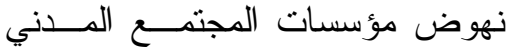
بوظائفها الأساسية في المجتمع مــن تثقيف، وتو عية، وتمنيـــل، ومطالبــة بالحقوق و الحريات. ץ- دور تربــوي يتحقـق مــن خــلال

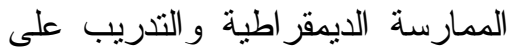
العمل على أسس الديمقر اطيـــة فــي الحياة الداخلية لمؤسـسـات المجتمــع المدني، منها: أ- وظيفة تجميع المصالح: من خــلد مؤسسات المجتمع المدني تتم بلورة مو اقـــ جماعيــة مـــن القــضايا و التحديات التي نو اجه أعــضاءها، وتمكنهم من التحرك جماعيًا لـــل

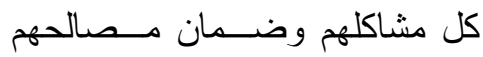
على أساس هذه المو اقف الجماعية، وتمارس هـــهـ الوظيفــة وبـشكل هله

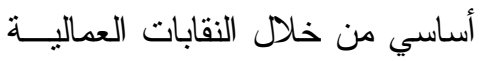

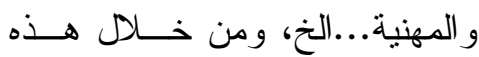
الوظيفة يتعلم الأعضاء كيفية بحث مشاكلهم ودر اسة الأوضاع القائمـــة 


$$
\begin{aligned}
& \text { د- إفراز وخلق التيارات الجيدة: وهي } \\
& \text { من أهم ملامح عمل هذه المؤسسات }
\end{aligned}
$$

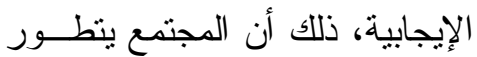

$$
\begin{aligned}
& \text { وتتضج حركة أعضاءه بقــدر مــــا } \\
& \text { يتوفر فيه من قيادات مؤهلة للسير }
\end{aligned}
$$

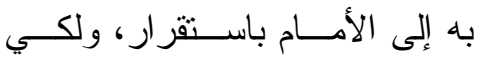

$$
\begin{aligned}
& \text { يو اصل المجتمع تقدمه فإنه بحاجــة } \\
& \text { دائمة لإعداد قيادات جديــدة مسن } \\
& \text { الأجيال المتتالية، وتكوين القبــادات }
\end{aligned}
$$

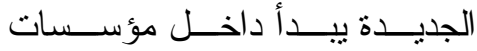

$$
\begin{aligned}
& \text { المجتمع المدني في النقابات المهنية } \\
& \text { و العماليــــة و الجمعيــــات الأهليــــة }
\end{aligned}
$$

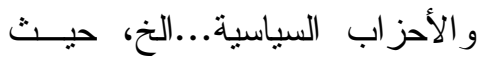

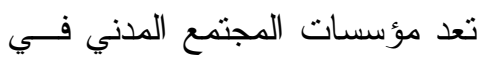

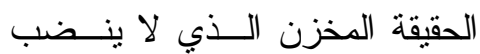

$$
\begin{aligned}
& \text { للقيادات الجديدة، ومصدرًا متجــددًا } \\
& \text { لإمداد المجتمع بها، فهي تجت ذبـ } \\
& \text { المو اطنين إلى عضويتها وتمكـنهم } \\
& \text { من اكتشاف قدر اتهم مـن خـــلال } \\
& \text { النشاط الجماعي وتوفر لهم الخبرة }
\end{aligned}
$$

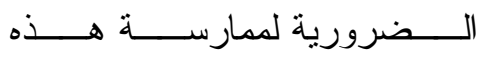

$$
\begin{aligned}
& \text { الممارسات و المـسؤوليات وبــذلك } \\
& \text { تساهم مؤسسات المجتمع المدني في }
\end{aligned}
$$

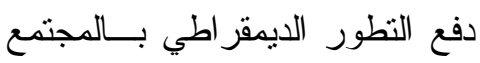

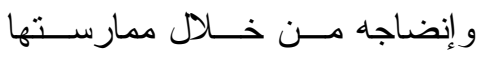

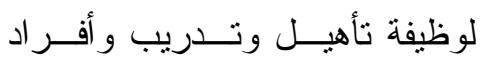

$$
\begin{aligned}
& \text { القيادات الجديدة أو المتميزة التـي وني }
\end{aligned}
$$


المؤسسات، وهذا القيم هـي فــي

$$
\text { مجملها قيم الديمقر اطية. }
$$

ومن هنا فإن إثثاعة الثقافـــة المدنبـــة

التي تمكن لهذه القيم في المجتمع هي خطوة

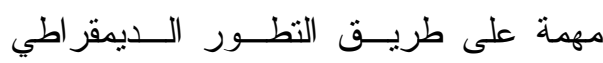
للمجتمع، حيث يستحيل بناء مجتمــع مسـدني

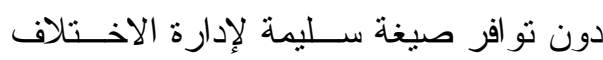

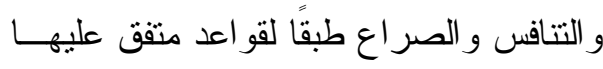

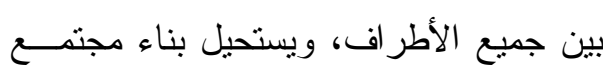

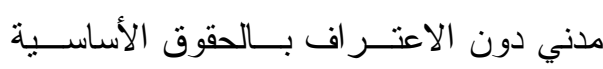

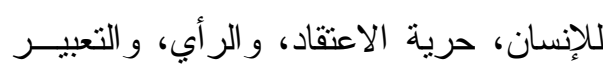

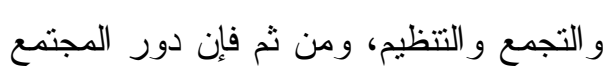

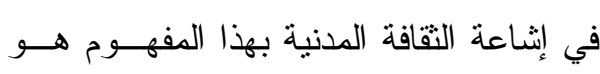
تطوير ودعم للتحول الديمقر اطي في نفس فـس فئس

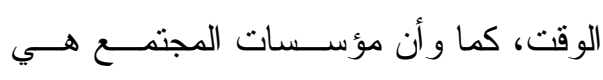
مدرسة الديمقر اطية الرئيسية في المجتمعات المتطورة الحديثة، حيث تقوم بإثـاعة ثقافـــة

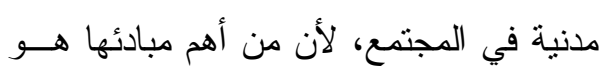

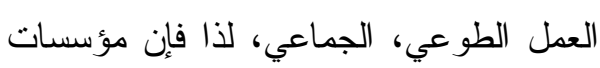

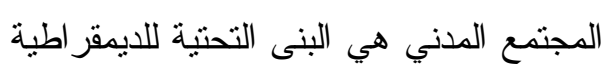

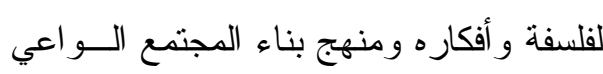
و المتماسك بشكل منطقي في سياسات التتظيم

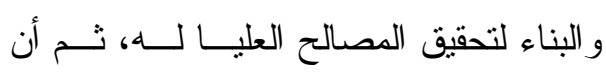

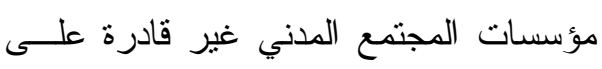

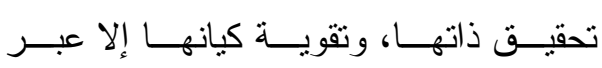
الديمقر اطية، إذن العلاقة تبادلية ومنز ابطــــة،

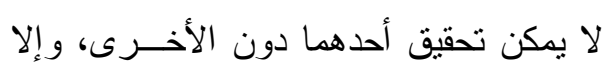

ليس لها انتماءات حزبية تحتضنها، بقدر ما تتمتع تلك المؤسسات مــن

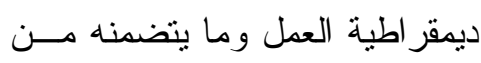
معاني وتطبيق عملي، تعمل هـــه المؤسسات على خلق قيادات فعالة ونــشطة، وقـــادرة علــى تحمـــل المسؤولية من خــال ممارســتها

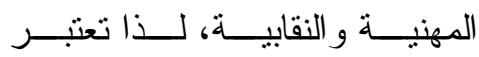
مؤسسات المجتمع المدني خزين لا لا لهابل ينضب للقيادات الجديـــدة المؤهلــــة

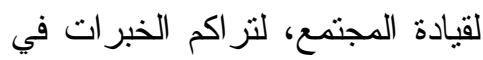

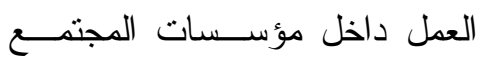

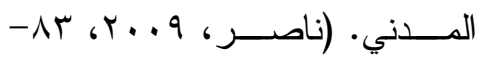
- - إثناعة نقافة مدنية ديمقر اطية: مسـن

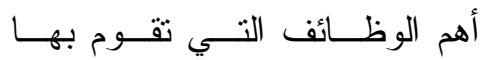
مؤسسات المجتمع المدني إثثــاعة

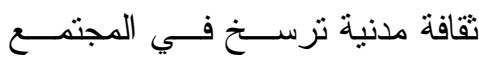

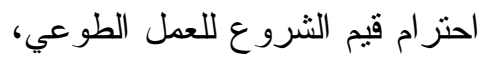
و العمل الجماعي، وقبول الاختلاف و التتوع بين الذات و الآخر ، و إدارة الخلاف بوسائل سليمة في ضـــوء

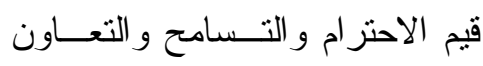

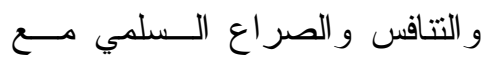
الالتز ام بالمحاسبة العامة و التقافيـــة

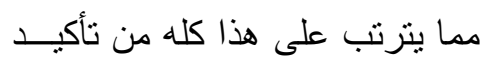

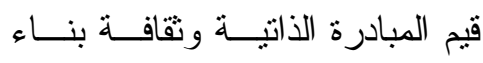


استثمار ا افتصاديا و اجتماعيا و إنسانياً بعيـــ المدى من الطراز الأول. وهــــا الاســتثمار

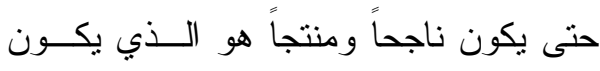

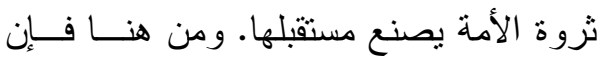
تعاون بين منظمات المجتمع المــدني ومــــع المؤسسات الرسمية في تحسين اقتـصاديات التعليم وفي تمويل مشروعات التعليم النوعي

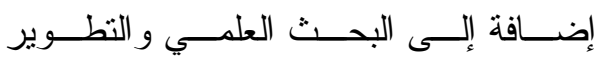
التكنولوجي باعتباره الجزء المكمل للتعلــيم

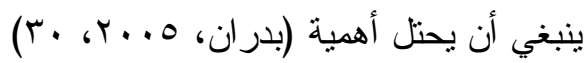
فنجد أن منظمات المجتمع المدني تبذل جهوداً اكبيرة في تتفيذ البر امج التعليمية وفقاً لخطط تتموية تضعها الحكومات بل أصبحت هذه المنظمات في العديد من الأقطار تشارك حكو ماتها في وضع الخطط وتأخذ على عاثقها تتفيذ البر امج التي لا ينسنى للحكومات تتفيذها .

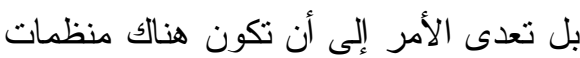

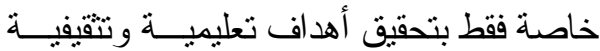
بحتة للرقي بمستوى التعليم ودعمه.

وتتسم علاقة منظمات المجتمع المدني

بالمؤسسات التزبوية الحكومية بأنها علاقات غير ثابتة، بسبب عدم الوضوح في العلاقــــة بين المنظمات و المؤسسات التعليمية، وسيطرة مجموعة من الأشخاص على هذه المنظمات،

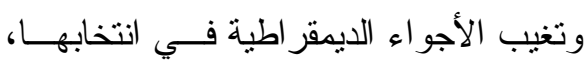

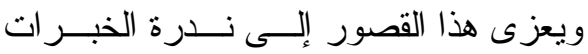
و إلمو إرد، بجانب تقييد الحريات، لذلك علــى لــ
فقد الاثثـان المعنــى و الوجــود. (ناصــر، $(\Lambda 7-10,4 . .9$

كما أنه في ظل دولة استبدادية سوهي

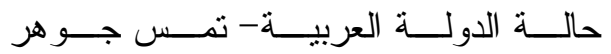
وصلاحيات السلطات النشريعية و القـ ضائية، ينتج عن ذلـــك تغيـــبـ الرقابــة القــضائية

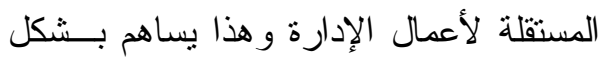
كبير في فقدان الحقــوق و الحريــات، هــــا بالإضافة إلى عدم خضوع التشريعات التـي تصدر ها الدولة، للرأي العام المتكون عبــر الحوار العقلاني الحر الذي يسعى إلى تحقيق

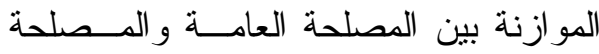

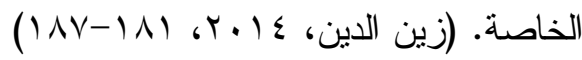
ثانياً - دور منظمات المجتمع المدني في

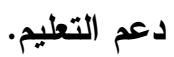
يعد التعليم اللبنة الأساس في صـرح التتمية فبدونه لا يحسـسن الفــرد اســتخدام

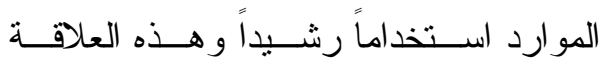

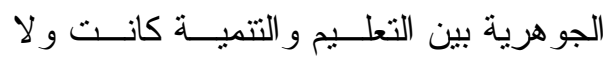
زالت محط اهتمــام كـل مــن المهتمـين و الباحثين فــي مجــال التتميـــة الحقيقيـــة؛

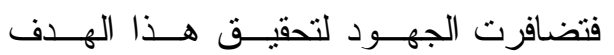
وتشاركت منظمات المجتمع المدني لتساند دور الحكومات للرقي بمسنوى التعليم هناك الكثير الذي ينظر إلــى التعلــيم

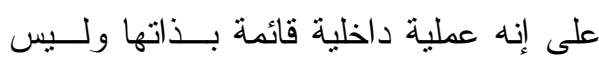


المدرسة ما ينبخــي تدريسـسه و علــى

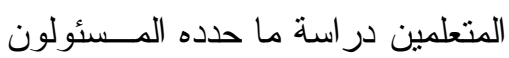

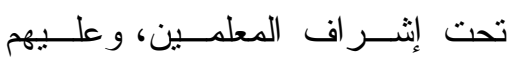
الحضور إلى المدرسة بانتظام وفـي

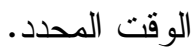

r. التعليم التلقائي : ما يتعلمه الفرد خلا ممارسته لحياته اليومية فالطفل يــتعلم اللغة بالاستماع للآخرين وهم يتحدثون ثم يحاول التحدث كما يفعلون ويـتعلم

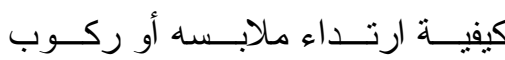

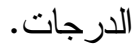

r. التعليم غير الرسمي : يحتل مكانــة

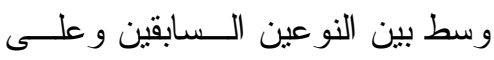

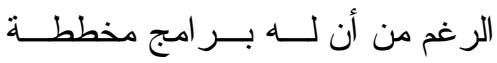
ومنظمة كما هو الحال فــي التعلــيم النظامي فإن الإجـــر اءات المتعلقــــة بالتعليم غير الرسمي أقل انضباطا من الإن

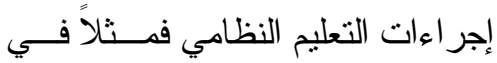
الأقطار التي يوجد بين سكانها من لا لا يعرفون القر اءة و الكتابــة اثنــتهرت طريقة كل متعلم يعلم أميــاً بوصـــهـاً

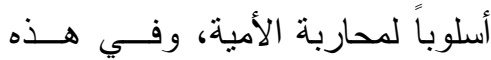

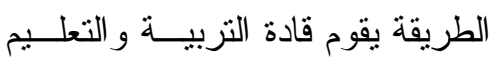
بإعداد مادة مبسطة لتعلــيم القـــر اءة و الكتابة و الحساب ويقوم كل مــتعلم بتعليمهم لو احد ممن لا يعرفونهم وقد

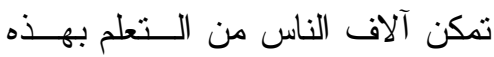

هذه المنظمات من نقابات مهنية، و عماليــة،

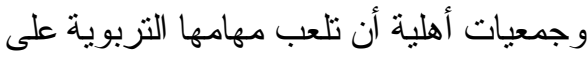
أكمل وجه من الوصـــول لــرؤى عقلانيــة

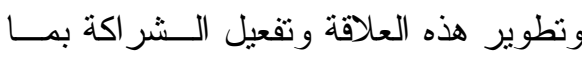
يخص الخدمات التعليمية المقدمة مــن قبــل التتظيمات، ونتيجة غياب رؤيـــة مجتمعيـــة و اضحة لدور ها في المشاركة في الإصـــلاح

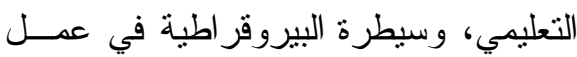

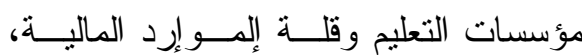
و الانفتاح الثقافي غير المرنبط بخـصوصنية

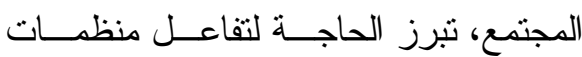

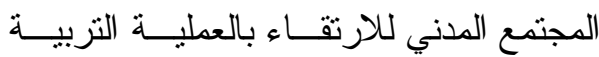
ويتطلب تحسين التعليم ، مشاركة من منظمات المجتمع المدني ذات الصلة بالتعليم، فكثيــر منها ينشط في مجــالات تــدريب المعلمـين بــين وتطبيق استر اتيجيات حديثة فـي التـدريس، ولديها من الدعم المادي و الاستشاري ما يكفي

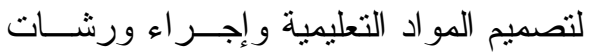

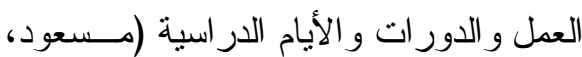
$\left(r-r_{6} r^{2}\right) V$

\section{ويصنف سيد والجمل التعليم لأنواع وهو:}

1. التعليم النظامي : تعليم يتلقاه المـتـعلم

في المدرسة وغالبا ما يعرف بالتعليم

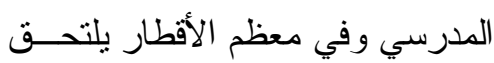

الناس بشكل من أثكال التعليم النظامي

خلال مرحلة الطفولة وفي هذا النوع لنئل

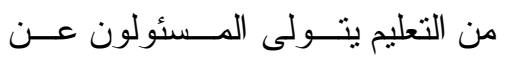


فيما بينها، وتتجاوز إيــديولوجياتها لتــؤمن

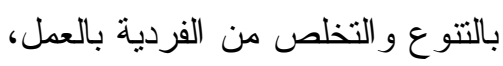
يجعلها أكثر إحاطة بالمشكلات التعليمية و أكثز قوة و أعمق دور ا، ويتيح لها الوصول إلى أكبر

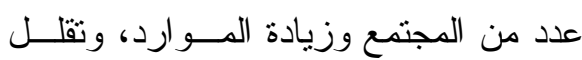

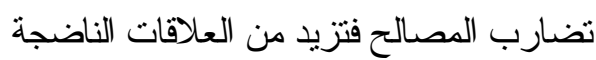

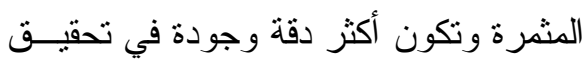

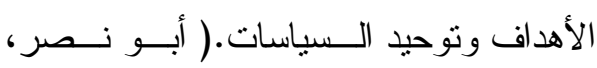

$$
\text { ( T }\{\text { r...V }
$$

وللنهوض بالعملية التزبوية وتـــوفير

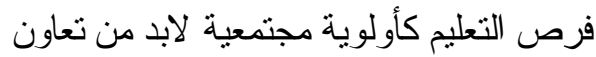

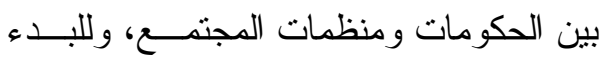
بالإصلاحات يجب البحث في إصلاح الجذور

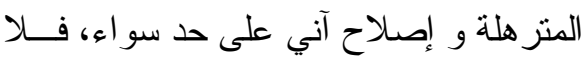
يمكن إصلاح ما هو بين أيدينا دون بناء قاعدة إنهاء أساسية سليمة خالية من الإخفاقات بحيث يتم التركيز على الدفاهيم والأهداف و الأولويات و هذا يتطلب وقتاً وجهاً لتمكينه على أرض الهد ولئ

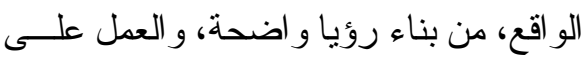
تتفيذها من خلال نقل الأهداف التربوية التـي وني وني

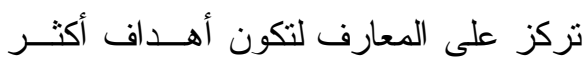
استكشافاً و إبداعا، وتحويل المعلم إلـى دور الوسيط، طالب محور للعمليــة التعليميــة، و وعدها تكون العملية التربوية هـــي عمليـــة

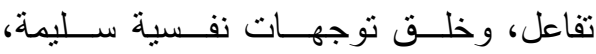
و إخلاص بالعمل و إن الإصلاح الآنـي مــن فئن

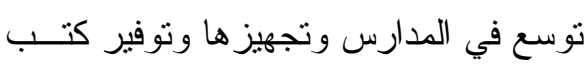

الطريقة غير الرسمية في البلاد العربية وفي بعض المجتمعات مثل الــصنين

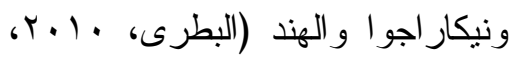

ولتحقيق تتمية شــاملة ودوراً أكثــر

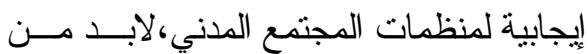
العمل ضمن سياسة التكامل في الأدوار فعلى لإلى لإنى

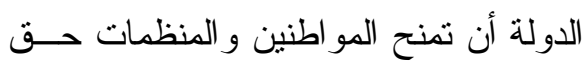
تقرير مصريهم و إعطائهم حقوقهم على أكمل

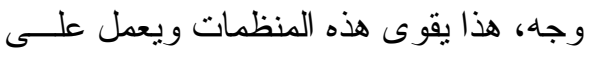
تذوب الصر اعات و المنافسة لتحفز التطلــع على ألإنجاز وتعويض النقص، ويجعلها أكثر

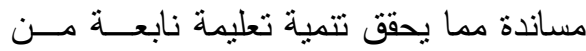
احتياجات المجتمع، ووضع خطة وتمويلهــا، ويحقق النز اهة و المحاسبة، وفي النهاية لابد من نطبيق سيادة القـانون وحظـــر الفـــاد

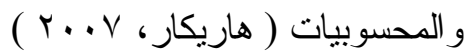

يشير (سالم) على ضــرورة انتـشار المنظمات في جميع مناطق الـــوطن و عـــدم تمركز ها في مناطق معينـــة، و هــــا يـــؤدي لتوزيع الأنشطة وبناء رؤيتها على احتياجات المجتمع ككل، وتطوير بر امجها و عدم الالتز ام بأجندة الممول و الاعتماد على الــــات و عـــدم

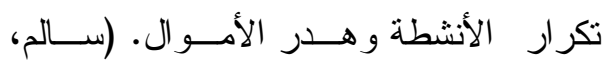
$(V, T \cdot G q$

هنا لابد من التتسيق بـين منظمــات المجتمع المدني و التعاون و التحالف و التشبيك لهيك 
وجمعيات أهلية أن تلعب مهامها التربوية على

أكمل وجه من الوصـــول لــرؤى عقلانيــة

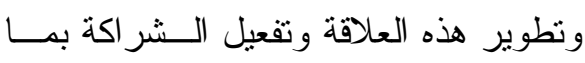

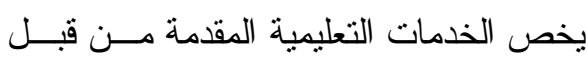

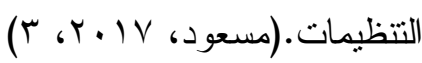

إن ضرورة انتشار المنظمات في جميع مناطق الوطن و عدم تمركز ها فــي منـــاطق

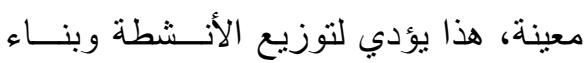

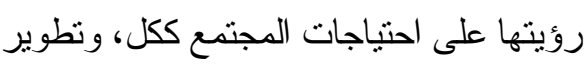

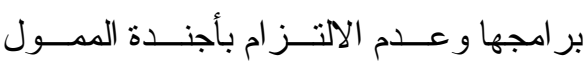

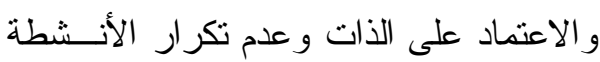

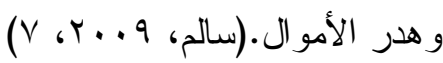

لذا بات من الضروري أن تتخذ بعض التران

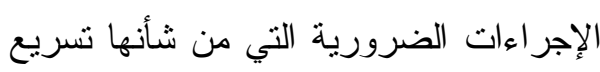

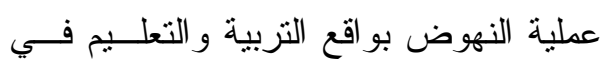
العراق، وهي إجر اءات اتبعتها جميع الــدول لـوليه

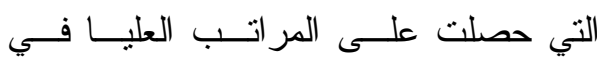
التصنيفات العالمية لمستوى التعليم وجودتـــه منل سنغافورة وكوريا الجنوبية وكندا. ا ـ ينطلب إعداد قادة ندريب متميّزين في

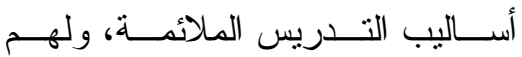

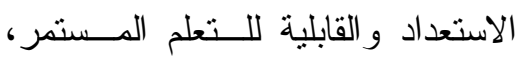
لتحقيق الأهداف و الملامح التي ذكرت أنفا و إكسابهم مهار ات وقدر ات تتتاسب

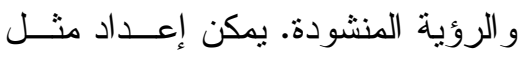
هذه الكو ادر من خلال الاستفادة مسنـ

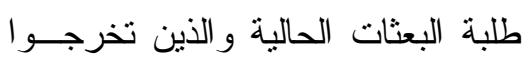

ووسائل تعليمية وتدريب معلمـين مــلازم لإصلاح الجذور مع مر اعاة التطور العالمي

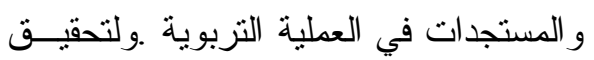
ذلك لابد من استغلال نقاط القوة و الاهتمــام المجتمعي و لأهلي ومنظماته، و الاستفادة مسنـ المساعدات الخارجية و من صغر حجم النظام التعليمي، وصغر عدد السكان، وتوفر كفاءات

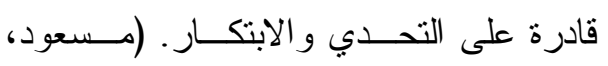
$(r \wedge, r \cdot) V$ فنجد أن منظمات المجتمع المدني تبذل جهوداً ا كبيرة في تتفيذ البر امج التعليمية وفقاً لخطط تتموية تضعها الحكومات بل أصبحت هذه المنظمات في العديد من الأفطار تشارك حكوماتها في وضع الخطط وتأخذ على عاتقها تتفيذ البر امج التي لا يتسنى للحكو مات تتفيذها .

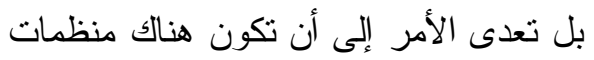
خاصة فقط بتحقيق أهداف تعليميــة وتثقيفيـــة بحتة للرقي بمسنوى التعليم ودعمه.

وتتسم علاقة منظمات المجتمع المدني

بالمؤسسات التزبوية الحكومية بأنها علاقات غير ثابتة، بسبب عدم الوضوح في العلاقــــة بين المنظمات و المؤسسات التعليمية، وسيطرة

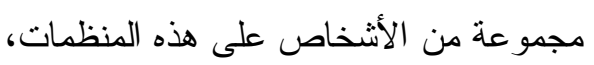

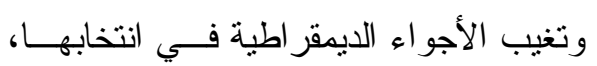

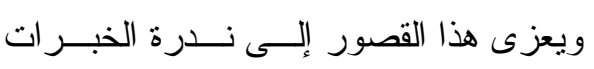

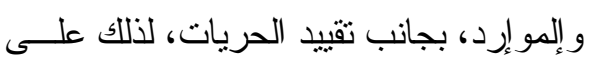
هذه المنظمات من نقابات مهنية، و عماليـــة، 
باستمر ار ، و لابـــد مــن وجــود هـــــ

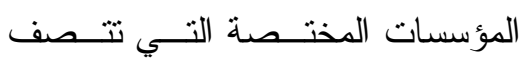

بالمسؤولية العامة نحو البلد، وتـساهم

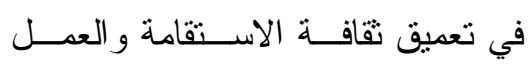

التطوّعي وتكون مسؤولية عن إبــراز

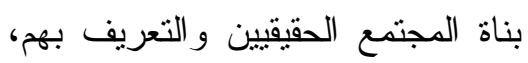

وكذلك إيراز النجاحات التي تحـصل ولتعل

بالعر اق باستمر ار، ومن أجل تحفيـز

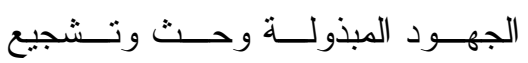

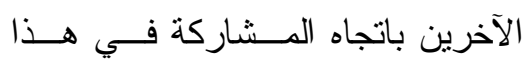

النوع.

ففي مجال التربية و التعليم نحن بأمس

الحاجة إلى مؤسسة مستقلة تساهم وتتكامل

مع المؤسسات الحكومية و الجهات المعنية بالتعليم وتؤدي دور ا في الدعم و المساندة، من

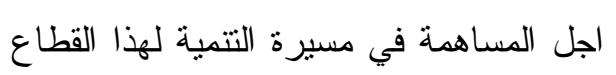
الحيوي، وبمعنى أدق هو القيام بإجر اءات التقييم و التقويم المستمرين من أجل منافسة الحكومة على ثقة الناس ورضاهم، وتحديدا تتولى ما يأتي على

ا ـ اختيار المعــايير المحــددة و اللازمـــة

لاستدامة نظوير قطاع التربية و التعلــيم

وجودنه، و اعتمادها في منح الاعتمادية

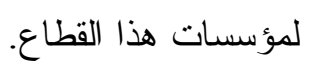

r. نشر الوعي المتعلــق بمعـايير جــودة

مؤسسات التربية و التعليم العـالي بــين بــين
في التخصصات التزبوية أو استقطاب

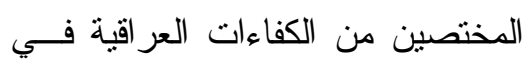
الخار ج للمشاركة في تدريب وتطــــير

التدريسيين في مراكز التـدريب ذات الرؤية الجديدة، أو إرسال مجموعة من فرن

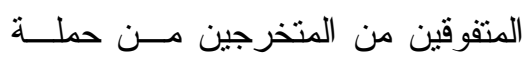

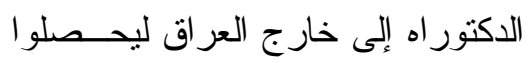
على شهادات مهنية في فترة لا تتجاوز

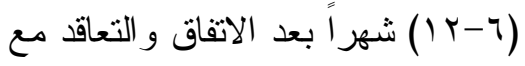
مر اكز متخصصة أو جامعات مرموقة الفي

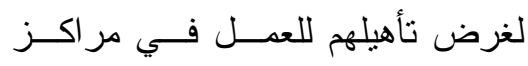
التدريب و التطوير المشار إليها. وهذه المر اكز هي التي ســتتولى التــدريب و التطوير وستكون حلقة الوصل مــــ

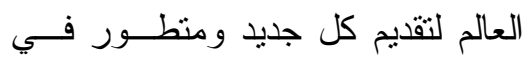

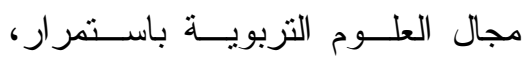

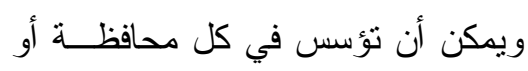

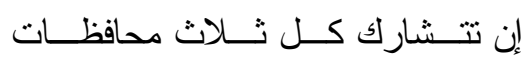

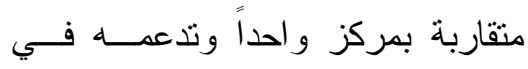
الوقت الحاضر ، و الذي يتطلب قـــــاراً على مستوى الحكومات المحلية. r. ضرورة وجود مؤسسات مجتمع مدني تشارك في صناعة وتوجيـــه الــسياسة العامة و التزبوية، وتؤدي دوراً رئيسـساً

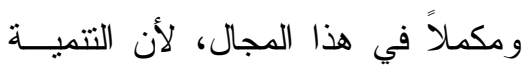
و التطوير لا يأتيا بالصدفة، بل تحتهـاج

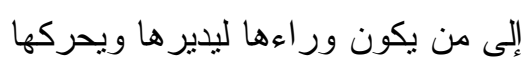


إطار مقترح للإصـلاح المدرسى تحديات

وطموحســات، 1V I 19 إيريـــل، كليـــة

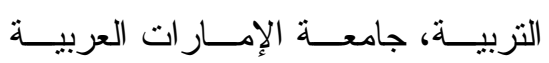
المتحدة.

ع- الكر اسنة، ســـيح و النحز اعلــه، تبيــر

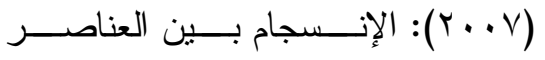

الإنسانية فى المدرسة كنظام ودورة فى المى

تحقيق الإصدلاح المدرسى، در اسة مقدمة

لمؤتمر الإصـلاح المدرســى :تحــديات

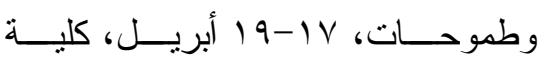

التربيــة، جامعـــة الإمـــار ات العربيـــة

المتحدة.

0- الياسرى، على عبد العزيــز (qهـ):

دور مؤسسات المجتمـــع المــدنى فـى

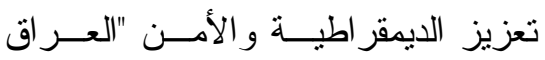

النموذجاً" بغداد، تشرين الأول، المكتبـــة

الوطنبة.

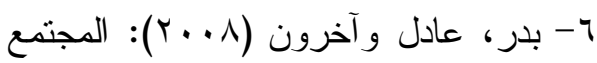

المدني وسياسات الحوار حول التعلــيم

للجميع في المنطقة العربيــة، منظمـــة اليونسكو، ص 9، مناح علي

http://portal.unesco.org/education/ en/files/54116

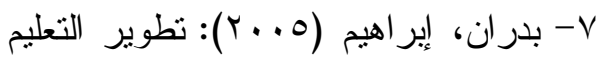

العالى فى مصر وتحــديات المـستقبل،

قر اءات ودر اســات، مكتبـــة الـششروق

الدولية، القاهرة.
أفر اد المجتمع من أجل حمـــايتهم مــن الاستغلال وتدني مستوى مخرجاتها. r. السعي باستمر ار لتحديث قو اعد البيانات عن قطاع التزبية و التعليم ومقارنتها مع

$$
\text { المعايير الدولية. }
$$

ء. نشر ثقافة نأسيس أكاديميات متخصصة

بدلا من مدارس التعليم العام أو الكليات

$$
\text { الأهلبة. }
$$

ه. تأسبس مر اكز مؤهلة ومتطورة للقيــام

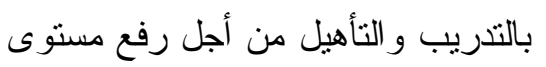
جودة التعليم، مع الاستمرار في تحديث نلك البر امج وفقا للحاجة وما بـستحدث في نفس الجانب. (فيصل، 7 ( • ب، 7 1)

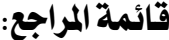

1- البطرى، محمد صالح حسـن ( • ب): تطوير التعلــيم الثـانونى العــام فـى الجمهورية اليمينة فى ضوء المتغيـر ات المجتمعية و العالمية، رسالة دكثور اه غير

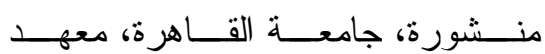
الدر اسات التربوية.

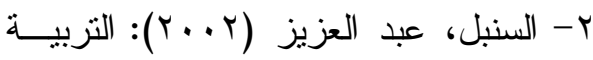
فى الوطن العربى على مشارف القــرن الحادى و العشرون، المكتــب الحــديث، الإسكندرية.

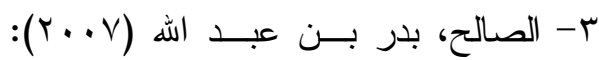

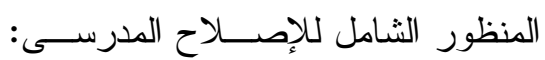




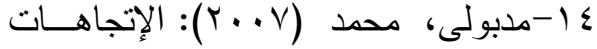

الحديثة فى تحسين المدرسة وتفعيلهـا

وعلاقتها بالنمو المعنــى للمعلمـين -

در استة تحليلة، كلية التربيـــة، جامعـــة

حلو ان.

10-مسعود، هناء عبـــد الله عبـــد الفنــاح

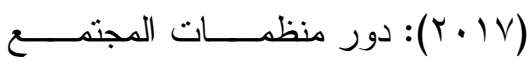

المدنى فى تطوير المنـــاهج وتحـسين

طرق التذريس فىى الــضفة الغربيــة،

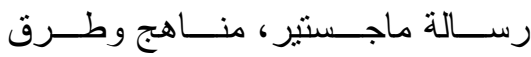

التدريس، كلية الدر اســات العليـــا فــى

جامعــــة النجـــــاح الوطنيــــة، نــــابلس،

فلسطين.

7 ا-مهرى، عبير سهام (0. . ب): العلاقـة

بين المجتمـــع المــدنى و الديمقر اطيــة

النموذج العراقى، مجلة در اسات عراقية

مركز العراق للار اســات و البحــوث،

$$
\text { العدد (r)، بغداد. }
$$

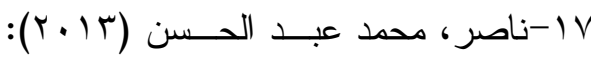

المتغبـــر ات المجتمعبـــة، و المــــــاتلات

التزبوية فى العراق، دراسة ميدانية فى

ورنية بغداد رســالة ماجـستير ، كليــة

$$
\text { الآداب، جامعة بغداد. }
$$

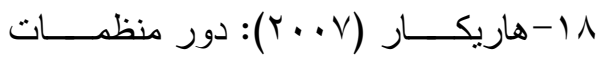

المجتمع المدنى فى التتمية الإجتماعية،

$$
\text { مطبعة ز انا، دهوك. }
$$

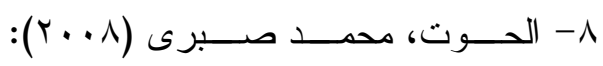

إصلاح التعليم بين و اقع الداخل وضغوط

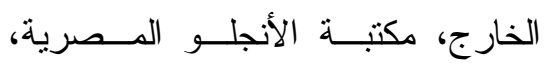
القاهرة.

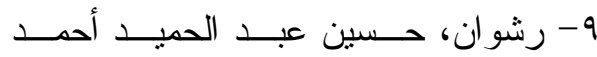

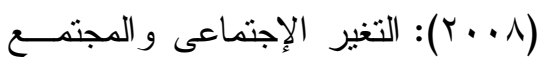

المكتب الجامعى الحديث، الإسكندرية.

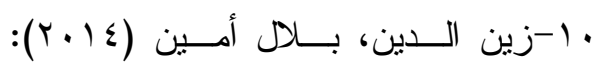

منظمات المجتمع المدنى فــى الــدول

العربية و الغربية، دار الفكر الجــامعى،

$$
\text { الإسكندرية. }
$$

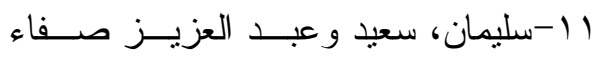

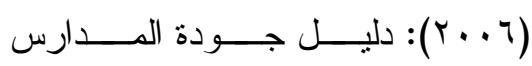

المصرية فى ضو ء المعــايير القوميــة

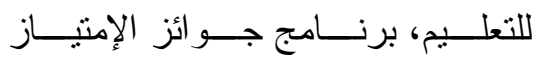

المدرســى "Esom"، للتعلـــيم، وزارة

التربية و التعليم، مصر •

Y ا-كريم محمد حمـزة (11 (Y): مسـشكلة

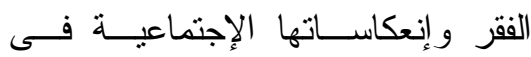

العر اق، بيت الحكمة، بغداد.

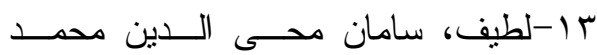

(10 ( ب): الحركات الإجتماعية ودورها

فى تغير المجتمع در اسة مبدانيــة فــى

إقليم كردستان، رسالة دكتـــور اه كليــة

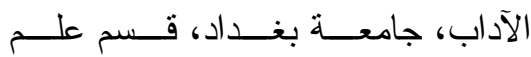

الإجتماع. 
21- Park, Hwanbo (2015): perceptions of Korean NGOS for education and educational development projects.

22- Peggy Mwanza, The Role of NGOs in achieving the Education for All Goals in Zambia, Journal of Librarianship and Information Science, v44 n1 p65-72 Mar

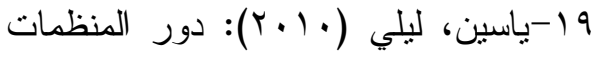

$$
\begin{aligned}
& \text { غير الحكومية في دعم التعليم في } \\
& \text { الأردن، رسالة ماجستير، كلية العلوم } \\
& \text { التربوية، الجامعة الهاثمية. }
\end{aligned}
$$

20- Corbin, J (2005): Increasing for school work practice resulting from comprehensive school reform, children and school. 